\title{
Transesterification Reaction and Morphology of PET/PEN Melt-mixed Blends and Their Flexural Strengths
}

\author{
Kensuke Mizufune, Kenichi SomA, Kenji NAgATA, Katsuhiro InOMATA, and Kiyohisa TAKaHASHI
}

Department of Materials Science and Engineering, Nagoya Institute of Technology,

Gokiso-cho, Showa-ku, Nagoya 466-8555, Japan.

\begin{abstract}
Poly(ethylene terephthalate) (PET) / poly(ethylene naphthalate) (PEN) blends with 50/50 composition have been prepared by melt-mixing at the temperatures above $280^{\circ} \mathrm{C}$ and subsequent heating at $280^{\circ} \mathrm{C}$ before hot-press molding. Progress of transesterification reaction and formation of PET-PEN random copolymers during these melt-blending processes have been confirmed by ${ }^{1} \mathrm{H}-\mathrm{NMR}$ measurement. Dynamic viscoelasticity, DSC thermograms, and SEM images for the PET/PEN blends with shorter heating time at $280^{\circ} \mathrm{C}$ suggested that the blend sample was in an immiscible state when the transesterification level (T) was less than 5\%. With the increase of the heating time, the sample changed to miscible state with $\mathrm{T}>5 \%$ and exhibited transparency. The phase-separated morphology was fine and the size of the phase-separated domain was several hundred nanometer when $\mathrm{T} \approx 5 \%$. Flexural test for the blend samples revealed that the PET/PEN blends exhibited the maximum flexural strength when $\mathrm{T} \approx 5 \%$. Increase in the meltmixing temperature was found to accelerate the transesterification reaction, and to shorten the processing time to obtain the miscible PET/PEN blend.
\end{abstract}

Key Words: Poly(ethylene terephthalate) / Poly(ethylene naphthalate) / Morphology / Melt-mixing / Transesterification / Flexural strength

\section{溶融混練 PET/PEN ブレンドのエステル交換反応と相構造および曲げ強度}

\author{
水舟 謙介，相馬 健一，永田 謙二，猪股 克弘，高橋＼cjkstart清久
}

(原稿受理：2004年3月22日）

\begin{abstract}
1. 緒言
ポリエチレンナフタレート1,2) (PEN) は，ポリエチレンテ レフタレート（PET）に比べ優れた機械特性, 耐熱性, 而薬 品性，高いガスバリア性を有するポリエステル樹脂である. 近年ではその特性を活かし, リターナブルボトル等の飲料用 ボトル, 化粧品, 薬品等の非飲料ボトル, 食器等の用途に使 われるようになっている. しかし, PENはPETに比べ高価で あるため, PEN単体で用いるにはコスト面において不利が大 きい. したがって, 安価でかつ構造の類似したPETをブレン ドすることによるPENの有効利用が期待され, 様々な研究が 行われている.

PET/PENブレンドに関する従来の研究では，両者を物理的 に混合しただけでは相分離系となることが報告されている.3.5) しかし, 融点以上で熱処理や溶融ブレンドを行うことで, PET とPENの間で化学的にエステル交換反応が起こり，生成した PET-PEN共重合体が相溶化剂として働くことで相分離系から 相溶系へと変化することが報告されている. ${ }^{3-9}$ またエステル
\end{abstract}

名古屋工業大学材料工学科

于 466-8555 名古屋市昭和区御器所町

Tel: +81-52-735-5262

E-mail : takahashi.kiyohisa@nitech.ac.jp
交換の反応度は，溶融温度と溶融時間に依存することが指摘

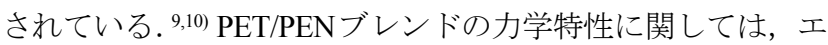
ステル交換反応が進行していない相分離系における延伸 フィルムの引張り特性が11)，エステル交換反応が進行した相 溶系におけるブレンド繊維の引張り特性が ${ }^{12,13)}$, 各々報告さ れている。 しかし，エステル交換反応の進行が力学特性に及 ぼす影響については報告例がない。

本研究では, PET/PENの50/50ブレンド試料を $280^{\circ} \mathrm{C} \sim 310^{\circ} \mathrm{C}$ の温度範囲で溶融混練した後, $280^{\circ} \mathrm{C} て ゙$ 熱プレス成形した. 熱 プレス成形を行う時間と, 溶融混練時の温度を変化させ，こ れらの成形条件がブレンド試料のエステル交換反応度や相 構造, 曲げ強度に与える影響について検討した。

\section{2. 実験}

\section{1 試料}

PETおよびPENは，TR-KBZおよびTN8065（帝人）を使用 した. 原材料中の水分を除去するために, 各ペレットを $120^{\circ} \mathrm{C}$ に設定した真空オーブン中で 8 時間減圧乾燥した. 乾燥した PET と PENのペレットを重量比50:50の配合割合になるよう に混合し，同方向回転2軸押出機（TECHNOVEL，KZW-15, 
$\mathrm{L} / \mathrm{D}=30$ ）を用いて，スクリュー回転数 $100 \mathrm{rpm}$ ，バレル設定温 度域（フィーダ側〜ダイ側） $280^{\circ} \mathrm{C} \sim 255^{\circ} \mathrm{C}, 290^{\circ} \mathrm{C} \sim 265^{\circ} \mathrm{C}$, $300^{\circ} \mathrm{C} \sim 275^{\circ} \mathrm{C}, 310^{\circ} \mathrm{C} \sim 285^{\circ} \mathrm{C}$ の各温度にて溶融混練を行い, 塊状試料を得た。得られた塊状試料を厚さ $2 \mathrm{~mm}$ の型枠 $(100 \mathrm{~mm} \times 100 \mathrm{~mm})$ 内に配置し, 酸化を防ぐためにアルミ箔で 密閉した後， $280^{\circ} \mathrm{C}$ 設定した熱プレス機内で所定時間（7分 〜87分）溶融し, その後直ちに $2.2 \mathrm{MPa}$ で1分間加圧した. 加 圧後は型枠ごと水冷プレス機に移し, 約 $25^{\circ} \mathrm{C}, 1.0 \mathrm{MPa}$ で 10 分 間通水冷却プレスを行い，厚さ $2 \mathrm{~mm}$ の板状試料を得た。 以下 では, 溶融混練に要する時間 (2分), 熱プレス上での溶融時 間 (7分〜 87 分), その後の加圧時間（1分）を合計した時間 （10分～90分）を，エステル交換反応時間とする.

\section{2 測 定 方 法}

動的粘弾性試験はDMS110（SEIKO電子工業）を用いて行

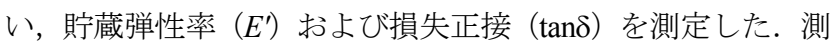
定は曲げモードで, 昇温速度 $2^{\circ} \mathrm{C} / \mathrm{min}$, 温度範囲 $30^{\circ} \mathrm{C} \sim 230^{\circ} \mathrm{C}$, 測定周波数 $1 \mathrm{~Hz}$ に設定し, 空気雰囲気下にて行った. なお, 本 研究では $\tan \delta$ の゚ーク温度をガラス転移温度 $\left(T_{\mathrm{g}}\right)$ と定義した。

示差走查熱量（DSC）測定はDSC220C（SEIKO電子工業） を用いて行い, 昇温時の結晶化温度 $\left(T_{\mathrm{c}}\right)$ および融点 $\left(T_{\mathrm{m}}\right)$ を測定した. 試料重量は $5 \sim 10 \mathrm{mg}$ とし, 昇温速度 $5^{\circ} \mathrm{C} / \mathrm{min}$, 温. 度範囲 $30^{\circ} \mathrm{C} \sim 300^{\circ} \mathrm{C}$, 窒素雾囲気下にて測定を行った。

三点曲げ試験はTENSILON/UTM-4（オリエンテック）を用 い, JIS K7203に準拠して行った. 試料寸法は50 mm × $15 \mathrm{~mm} \times$ $2 \mathrm{~mm}$, 支点間距離 $32 \mathrm{~mm}$, たわみ速度 $1 \mathrm{~mm} / \mathrm{min}$, 測定温度 $25^{\circ} \mathrm{C}$ の条件で測定した。
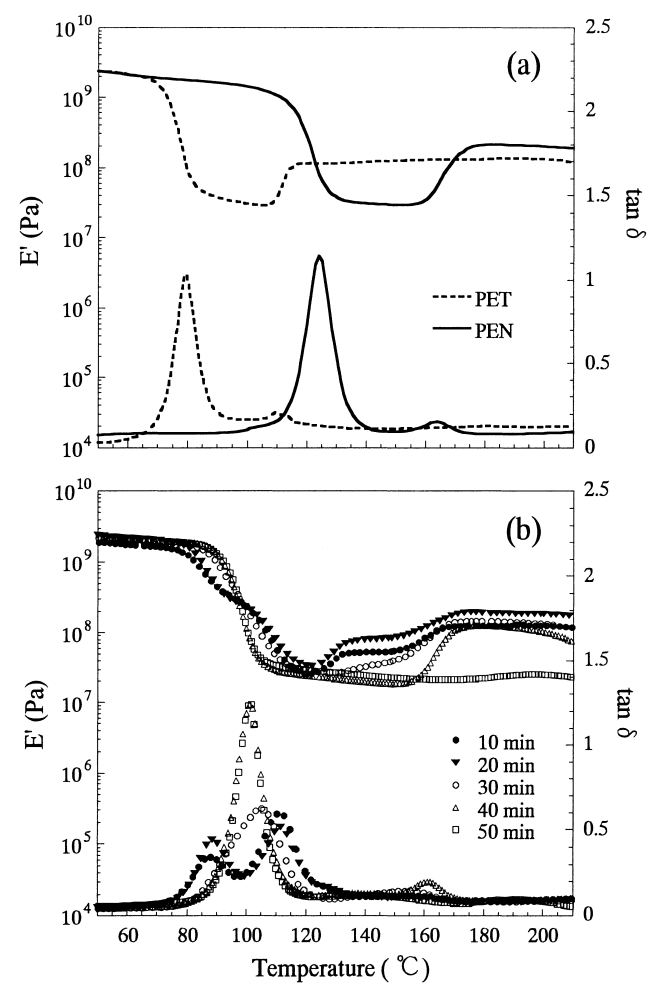

Fig.1 Storage modulus $E^{\prime}$ and loss tangent $\tan \delta$ vs. measured temperature of PET (- - - ), PEN (-), and the PET/PEN blends (50/50) reacted for $10(\bullet), 20(\nabla), 30(O), 40(\Delta)$ or 50 minutes $(\square)$.
モルフォロジーの観察は走査型電子顕微鏡（SEM，日立製 作所，S-2150型）を用いて行った。試料片を液体窒素中で凍 結破断し, ジクロロ䣷酸を用いてPET成分を溶出させた後, 真空下で金蒸着した破断面の観察を行った.

エステル交換反応の進行度は, 核磁気共鳴装置 AVANCE200 型（Bruker）を用いて得た ${ }^{1} \mathrm{H}-\mathrm{NMR}$ スペクトルより決定した. 溶媒として, 重水素化クロロホルムと重水素化卜リフルオロ 䣷酸の $3: 1$ (体積比) 混合物を用いた. 青木らのの報告を参考 にして，(1)式よりエステル交換反応度（T）を算出した。

$$
\mathrm{T}=\left\{\mathrm{I}_{\mathrm{NET}} /\left(\mathrm{I}_{\mathrm{NEN}}+\mathrm{I}_{\mathrm{NET}}+\mathrm{I}_{\mathrm{TET}}\right)\right\} \times 100(\%)
$$

ここで, $\mathrm{I}_{\mathrm{NEN}}, \mathrm{I}_{\mathrm{NET}}, \mathrm{I}_{\mathrm{TET}}$ はそれぞれ, ナフタレートーエチレン 一ナフタレート連鎖, ナフタレートーエチレンーテレフタ レート連鎖，テレフタレートーエチレンーテレフタレート連 鎖におけるエチレン鎖のプロトンに由来するNMRピークの 積分強度を表す.

\section{3. 結果と考察}

\section{1 溶融時間の影響}

エステル交換反応時間が相構造に与える影響について検 討するために，バレル設定温度域が $280^{\circ} \mathrm{C} \sim 255^{\circ} \mathrm{C}$ の条件で溶 融混練した塊状試料について，熱プレス機中 $\left(280^{\circ} \mathrm{C}\right)$ での 溶融時間を変化させた成形試料を作製した。動的粘弾性試験 の結果をFig.1に示す．溶融時間が最も短い試料（・, 反応時

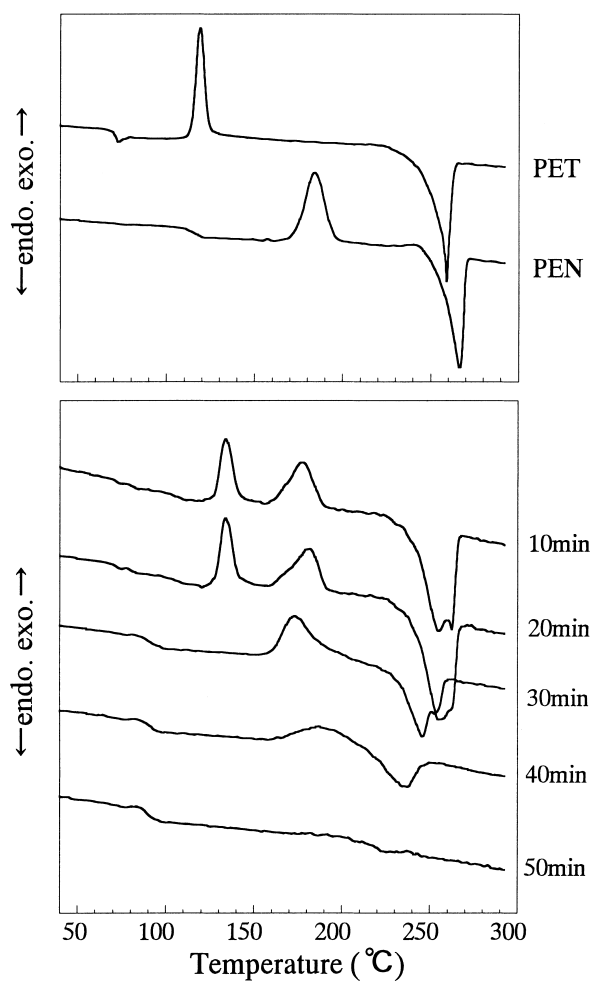

Fig.2 DSC heating thermograms of PET, PEN, and the PET/PEN blend $(50 / 50)$ samples reacted for $10,20,30,40$ and 50 minutes. 
間10分）では，Fig.1a との比較により明らかなように，低温 側および高温側にPETおよびPEN各々の $T_{\mathrm{g}}$ 帰属される2つの E'の低下と $\tan \delta$ ピークが観測され, PETとPENがマクロな相を 形成する相分離系であることが示唆される. 反応時間20分の

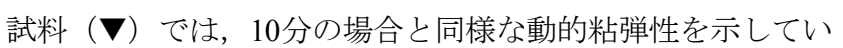
るが，30分 (O) では $E^{\prime} の$ 低下が1段階となり，それに対応す る $\tan \delta$ ピークもブロードではあるがほぼ単一になった。 さら に反応時間を 40 分 $(\Delta), 50$ 分 $(\square)$ と長くすると, $\tan \delta$ の ピー ク值の増加とともにピーク幅が狭くなったことより, 試料が 相溶系へ変化したと考えられる. 反応時間 30 分の試料では PET とPENは完全には相溶しておらず, 微細なPET相と PEN 相が共存した状態であると考えられる.

Fig.2にはDSC測定の結果を示す. PET, PEN単体のDSCカー ブより明らかなように, 反応時閒が 10 分と 20 分のブレンド試 料では, 低温側 $\left(\right.$ 約 $\left.135^{\circ} \mathrm{C}\right)$ にPETの, 高温側 (約 $\left.180^{\circ} \mathrm{C}\right)$ に PENの結晶化による $T_{\mathrm{c}}$ が別々に観測されることより，やはり マクロなPET相とPEN相が存在する相分離系であると考えら れる. 30 分反応させると, エステル交換反応の進行により PET およびPENの連鎖長が短くなり結晶性が低下寸るため, PET の結晶化ピークは消失し, PENの結晶化ピークは高温側にブ ロード化したものと考えられる.反応時間が40分の試料では, 30分の試料よりエステル交換反応が進行し相溶系となったこ とにより， $T_{\mathrm{c}}$ はさらに高温側にシフトし，また $T_{\mathrm{m}}$ の降下も観 測された. さらに反応時間が長い 50 分の試料では, $T_{\mathrm{c}} や T_{\mathrm{m}}$ が ほとんど確認できないことから, 非晶性の試料となったと考 えられる. 木村ら ${ }^{14)}$ は, PET/ポリアリレートブレンドではエ ステル交換反応の進行によってブロック共重合体を経てラ ンダム共重合体が形成されることを報告している. 本研究に おいても, PETとPENの間でエステル交換反応が進行しラン
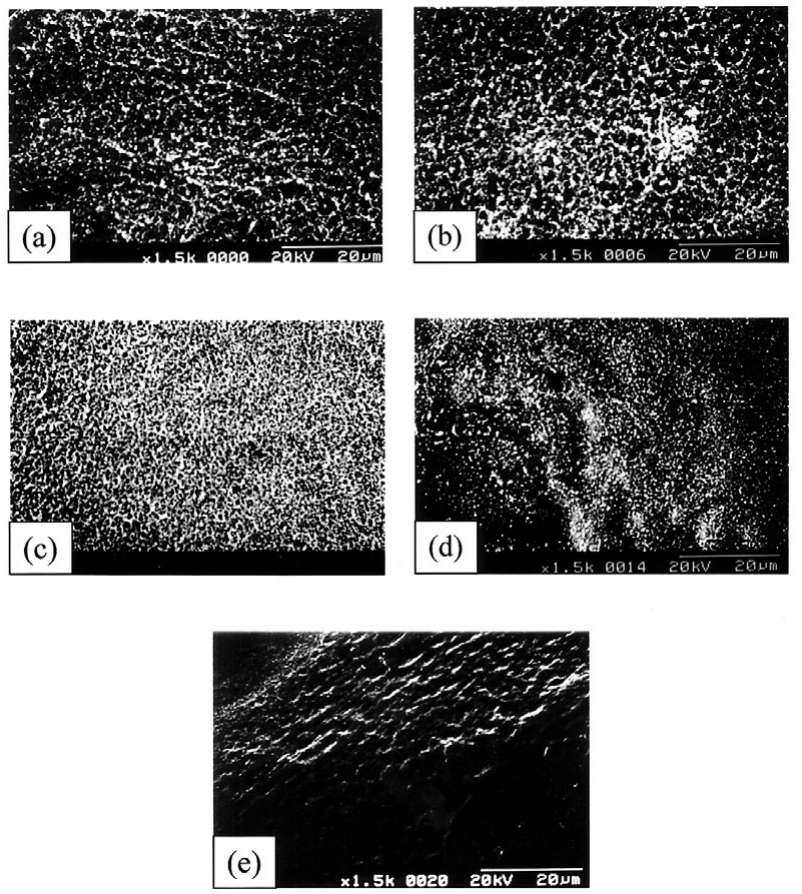

Fig.3 Scanning electron micrographs of fractured surfaces etched by dichloroacetic acid of the PET/PEN blend (50/50) reacted for (a) 10, (b) 20, (c) 30, (d) 40 and (e) 50minutes.
ダム共重合体が形成されたため, 結晶化が起こらなくなった ものと考えられる.

試料片を液体窒素下で破断した後, ジクロロ酢酸を用いて PET成分のみを溶出した破断面のSEM写真をFig.3に示す. 相

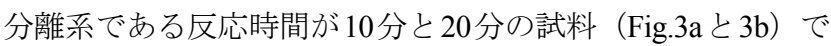
は，不均一な共連続構造が観察され，同一相間の間隔は 800 〜 $1600 \mathrm{~nm}$ であった. 同一の条件で成形したPETおよびPEN単 体の外観が透明であるのに対して，これらの試料がFig.4a，4b の外観写真で示されるように不透明で白濁しているのは，相 分離構造のサイズが可視光波長よりも大きいことが原因で ある.ある程度相溶性が向上した反応時間が 30 分の試料では, Fig.3cに示すように各相が緻密に入り組んだ均一な共連続構 造が観測された。この構造における同一相間の間隔は可視光 波長と同程度の $400 〜 800 \mathrm{~nm}$ であり，そのことを反映して， Fig.4cに示すように試料の透明性が増したと考えられる.さ らに反応時間が長いFig.3d，3eでは，相分離系の試料と比較 して平坦な表面が観察されており，また試料の外観はほぼ完 全に透明となった（Fig.4d，4e）。以上の結果からも，エステ ル交換反応の進行によってブレンド試料が相溶系に移行し たことが示される.

Fig.5には, ${ }^{1} \mathrm{H}-\mathrm{NMR}$ スペクトルより得られたエステル交換 反応度 $\mathrm{T}$ を反応時間に対してプロットした。 反応時間の増加 とともに $\mathrm{T}$ が増加し，エステル交換反応が進行していること が分かる．反応時間 30 分におけるTは約 $5 \%$ であり，既に説明 した動的粘弾性, DSCおよびSEM観察の結果を踏まえると, $\mathrm{T}<5 \%$ では相分離系， $\mathrm{T}>5 \%$ では相溶系であると指摘するこ とができる．この結果は，青木らのが報告している $\mathrm{T}<6 \%$ で 相分離系であるという結果とほぼ一致した。

以上の熱プレス上での溶融時間の影響については, PET/ PENの配合割合が 50/50以外のブレンド試料に関しても測定 を行ったところ，同様の結果が得られた.

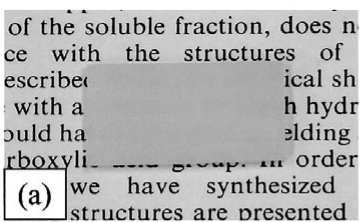

with the structures of th sscribed so far. Its chemical shift with a structure in whi h hydrol ,uld have taken place, elding a $c$ rboxylic acid group. 1 order ti sis, Wo have synt... sized th (c) structures are presented in

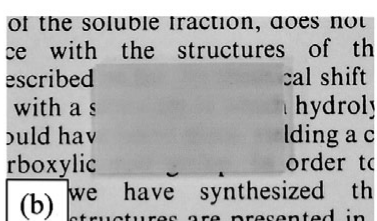

(b) we have synthesized th

\begin{abstract}
e with the structures of th scribed so far. Its chemical shift with a structure in which hydrols uld have taken place, yielding a $\mathrm{c}$ boxylic acid group. In order tc is, we have synthesized th

(d) tructures are presented in
\end{abstract}

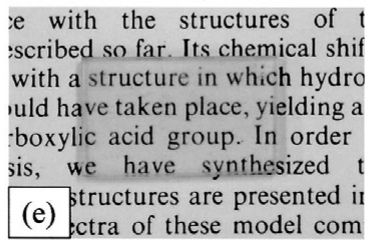

Fig.4 Photographs of the PET/PEN blend (50/50) samples reacted for (a) 10 , (b) 20, (c) 30, (d) 40 and (e) 50minutes. 


\section{2 溶融混練温度の影響}

前節では，2分間の溶融混練時の温度域を $280^{\circ} \mathrm{C} \sim 255^{\circ} \mathrm{C}$ に 固定して試料を作製した. 本節では，エステル交換反応およ びモルフォロジーに与える溶融温度の影響を検討するため, $290^{\circ} \mathrm{C} \sim 265^{\circ} \mathrm{C}, \quad 300^{\circ} \mathrm{C} \sim 275^{\circ} \mathrm{C}, 310^{\circ} \mathrm{C} \sim 285^{\circ} \mathrm{C}$ と $10^{\circ} \mathrm{C}$ ずつ高 く設定した条件で溶融混練を行い塊状試料を作製した。な お, その後の熱プレス機中での溶融温度は前節同様 $280^{\circ} \mathrm{C}$ に 固定した．溶融混練により機械的にPETとPENを混合させる ことで, エステル交換反応が効率よく進行することが期待さ れる.

Fig.6a〜 cには動的粘弾性試験の結果を示す. 混練温度 $290^{\circ} \mathrm{C}$ $\sim 265^{\circ} \mathrm{C}$ で作製した試料（Fig.6a）では，エステル交換反応時 間10分では2種類の $E^{\prime} の$ 低下と $\tan \delta$ ピークが観測され, 相分離 系であることが示唆される. 反応時間が 20 分以上になると, $\tan \delta$ ピークが単一化し相溶系に変化している. 前節の結果を 考慮すると, この状態ではPET相と PEN相が微分散している と推測される. 混練温度 $300^{\circ} \mathrm{C} \sim 275^{\circ} \mathrm{C}$ の試料（Fig.6b）では, 反応時間 10 分ですでに $\tan \delta$ は単一なピークを示しており, 相 溶系になっていることが示唆される. 混練温度をさらに $310^{\circ} \mathrm{C} \sim 285^{\circ} \mathrm{C}$ 上げた試料（Fig.6c）では, 反応時間 10 分で $\tan \delta$ ピークはすでにシャープであった.

エステル交換反応度の測定結果をFig.7に示寸. 動的粘弾性 の結果より, 混練温度 $290^{\circ} \mathrm{C} \sim 265^{\circ} \mathrm{C}$ では反応時間 20 分で, $300^{\circ} \mathrm{C} \sim 275^{\circ} \mathrm{C}$ では 10 分で相溶性の向上が示されることから， 前節で指摘したように, エステル交換反応度 $5 \%$ を境として相 分離系と相溶系に区別できることがわかる. 一方, $300^{\circ} \mathrm{C}$ 以 上の温度で混練した試料では, $290^{\circ} \mathrm{C} \sim 265^{\circ} \mathrm{C}$ 試料と比べて 反応度が低くなる傾向が見られる。 これは恐らく, 高温での 混練により分子量の低下が起こるのに対し, 反応度を求める (1)式が高分子鎖末端の影響を考慮に入れていないために, 反 応度が正確には求められていないことが原因であると推察 される.

以上の結果から, わずか 2 分間の溶融混練時の温度を高温 に設定することで, より短い溶融・熱プレス成形時間でエス テル交換反応が進行し，相分離系から相溶系に移行すること が明らかになった。

\section{3 力学物性}

PET/PENブレンドの溶融混練・熱プレス成形時のエステル 交換反応の進行とモルフォロジーの変化が, 試料の力学物性 に与える影響を検討するために，三点曲げ試験を行った. Fig.8には, 各混練温度で作製した試料の曲げ弾性率と曲げ強 度をエステル交換反応時間に対してプロットした．両者と も，概ねPET単体 $(2.6 \mathrm{GPa}, 80 \mathrm{MPa})$ およびPEN単体 $(2.3 \mathrm{GPa}$, $100 \mathrm{MPa})$ の中間程度の值となったが, 詳細に調べると, エス テル交換反忘の進行に伴い変化が見られた. 曲げ弾性率は, 測定誤差を考慮すると, 各温度とも反応時間の増加に伴いわ ずかに低下する程度であったが, 曲げ強度は, 混練温度が $280^{\circ} \mathrm{C} \sim 255^{\circ} \mathrm{C}$ では反応時間 30 分で, $290^{\circ} \mathrm{C} \sim 265^{\circ} \mathrm{C}$ では20分 で極大值を示した. また $300^{\circ} \mathrm{C} \sim 275^{\circ} \mathrm{C}$ 試料では, 反応時間 10分で他の試料よりも高い值を示した.これらの反応時間は, 各温度でエステル交換反応度が約 $5 \%$ になり, 相溶性が向上し て相分離系から相溶系へと移行する時間と一致する。すなわ ち, PET相とPEN相が微分散した状態で形成される緻密な相 構造（Fig.3c）が, 試料の曲げ強度を向上させているものと推

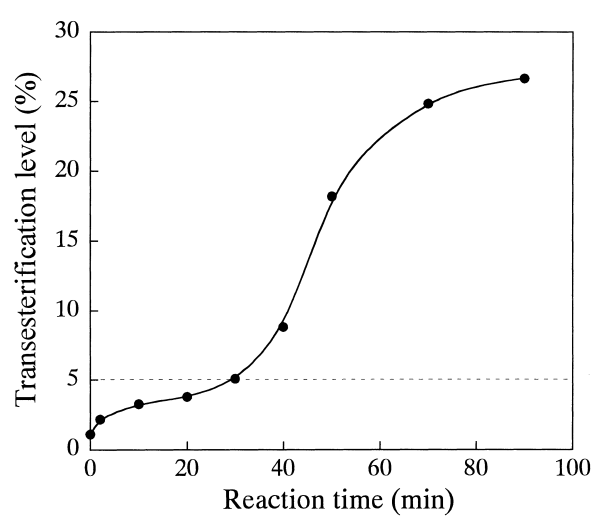

Fig.5 Transesterification level as a function of reaction time for the PET/PEN blend (50/50).
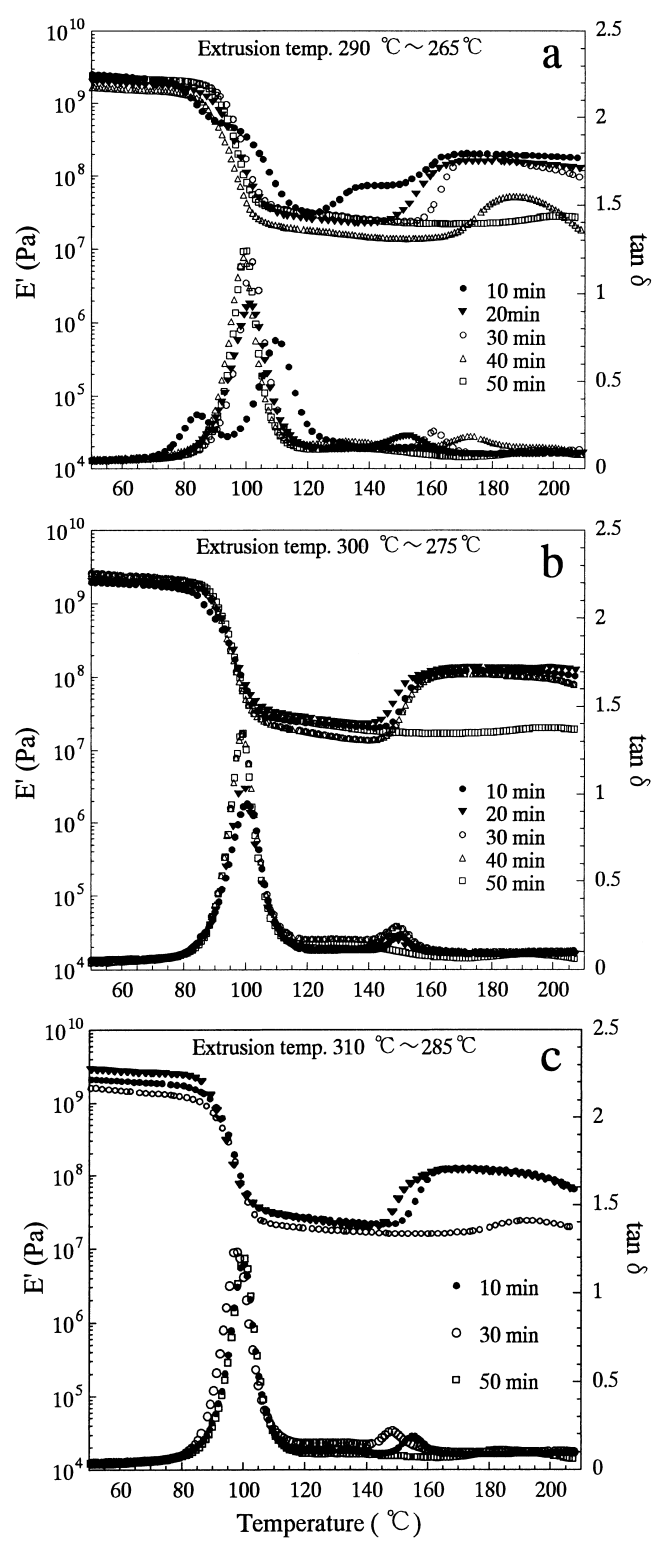

Fig.6 Effects of melt-mixing temperature on the storage modulus $E^{\prime}$ and loss tangent $\tan \delta$ of the PET/PEN blend (50/50) reacted for 10 $(\bullet), 20(\boldsymbol{\nabla}), 30(\mathrm{O}), 40(\triangle)$ or 50 minutes $(\square)$, respectively. The melt-mixing temperature is (a) $290-265^{\circ} \mathrm{C}$, (b) $300-275^{\circ} \mathrm{C}$, and (c) $310-285^{\circ} \mathrm{C}$. 
察される．ブレンド試料の相溶性が増すことによる力学物性 の向上は, Mondragon ${ }^{15)}$ によるポリカーボネート/PETブレン ド系の引っ張り強度測定においても報告されている. 一方, 混練温度 $300^{\circ} \mathrm{C} \sim 275^{\circ} \mathrm{C}$ で反応時間 40 分以上, あるいは混練温

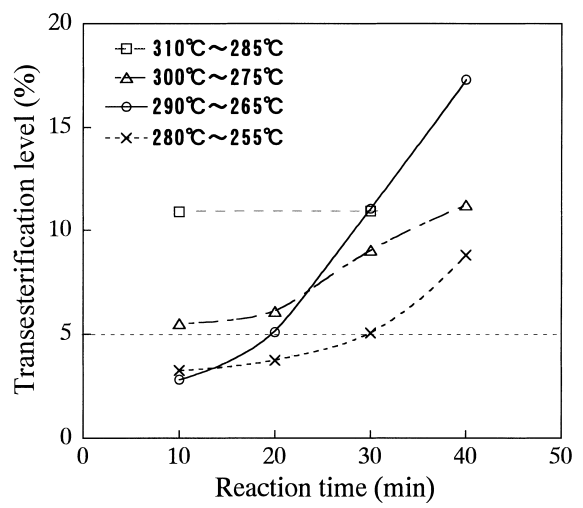

Fig.7 Transesterification level vs. reaction time of the PET/PEN blend (50/ 50) samples extruded at $280-255^{\circ} \mathrm{C}(\times), 290-265^{\circ} \mathrm{C}(\mathrm{O}), 300$ $275^{\circ} \mathrm{C}(\triangle)$, and $310-285^{\circ} \mathrm{C}(\square)$, respectively.
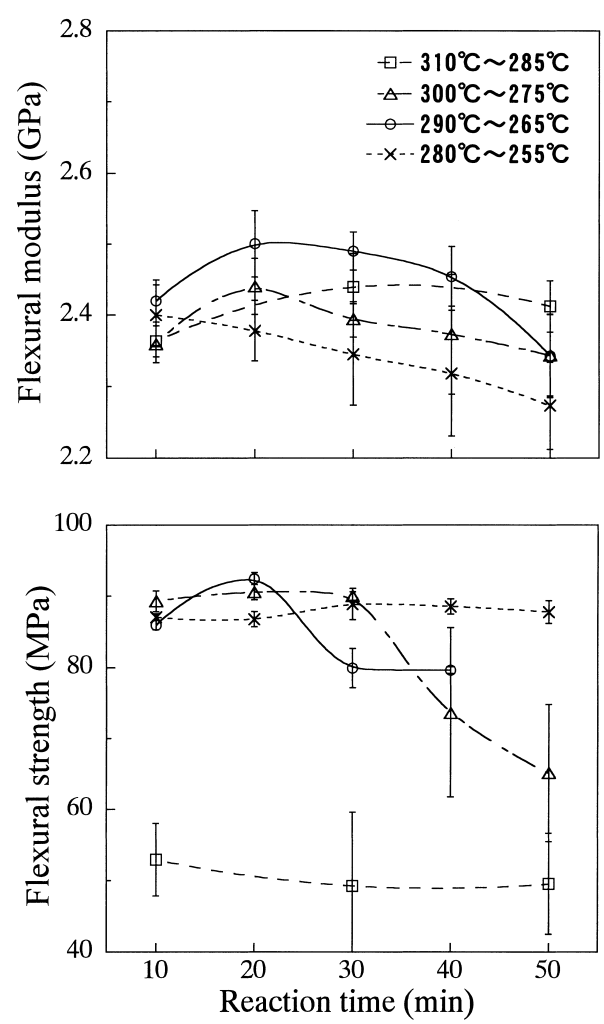

Fig.8 Flexural modulus and strength vs. reaction time of the PET/PEN blend (50/50) samples melt-mixed at $280-255^{\circ} \mathrm{C}(\boldsymbol{X}), 290-265^{\circ} \mathrm{C}$ $(\mathrm{O}), 300-275^{\circ} \mathrm{C}(\triangle)$, and $310-285^{\circ} \mathrm{C}(\square)$, respectively.
度 $310^{\circ} \mathrm{C} \sim 285^{\circ} \mathrm{C}$ 試料では, 曲げ強度の大幅な低下が観測さ れた。 これは，前節で指摘した，高温での混練により分子量 低下が起こっていることが原因と考えられる.

以上の結果から，溶融混練・熱プレス成形した PET/PEN (50/50) ブレンド試料では，エステル交換反応度を $5 \%$ になる ように成形することで，試料の曲げ強度が極大を示すことが 明らかとなった。

\section{4. 結 論}

PET/PEN（50/50）ブレンド試料の溶融混練・熱プレス成形 を行い，溶融時のエステル交換反応の進行に伴うブレンド試 料の相溶性や，モルフォロジー，力学物性の変化について検 討した。混練温度を $280^{\circ} \mathrm{C} \sim 255^{\circ} \mathrm{C}$ に固定した場合，エステル 交換時間が30分の時に相分離系から相溶系に変化し始め，試 料片は透明性を増し，PET相とPEN相が微分散した緻密な相 構造が形成された.この時間でのエステル交換反応度は $5 \%$ で あり，これより反応時間が短く反応度が低い場合には相分離 系, 反応時間が長く反応度が高い場合には相溶系であった. 2 分間の溶融混練時の温度を高くすると，より短いエステル交 換反応時間で相分離系から相溶系への移行が起こることが わかった。これらの試料の三点曲げ試験を行ったところ，エ ステル交換反応度が $5 \%$ で緻密な相構造を形成している場合 に，曲げ強度が極大值を示すことが明らかとなった。

\section{REFERENCES}

1) Ogawa K, Purasuchikkusu, 54, 67 (2003).

2) Tamura H, Purasuchikkusu, 53, 114 (2002).

3) Ihm DW, Park SY, Chang CG, Kim YS, Lee HK, J Polym Sci Part A Polym Chem Ed, 34, 2841 (1996).

4) Okamoto M, Kotaka T, Polymer, 38, 1357 (1997).

5) Bang HJ, Lee JK, Lee KH, J Polym Sci Part A Polym Phys Ed, 38, 2625 (2000).

6) Aoki Y, Lee L, Amari T, Nishimura K, Arashiro Y, Macromolecules, 32, 1923 (1999).

7) Denchev Z,Ezquerra TA,Nogales A, Sics I,Alvarez C,Broza G, Schulte K, J Polym Sci Part B Polym Phys Ed, 40, 2570 (2002).

8) Becker O, Simon GP, Rieckmann T, Forsythe JS, Rosu RF, Völker S, J Appl Polym Sci, 83, 1556 (2002).

9) Stewart ME, Cox AJ, Naylor DM, Polymer, 34, 4060 (1993).

10) Shi Y, Jabarin SA, J Appl Polym Sci, 80, 2422 (2001).

11) Ito M, Takahashi M, Kanamoto T, Polymer, 43, 3675 (2002).

12) Kyotani M, Pudjiastuti W, Saeed A, J Macromol Sci Phys, 38, 197 (1999).

13) Wu G, Cuculo JA, Polymer, 40, 1011 (1999).

14) Kimura M, Porter RS, J Polym Sci Polym Phys Ed, 21, 367 (1983).

15) Mondragon I, J Appl Polym Sci, 32, 6191 (1986). 